$104: 560$

<短 報 $>$

新しい腫瘍マーカーATM-1の肝細胞癌における臨床的意義

\begin{tabular}{rrrlll} 
井䞤 & 道夫 & 中村 & 郁夫 & 大西 & \multicolumn{1}{l}{ 真 } \\
石川 & 隆 & 森山 & 貴志 & 油谷 & 浩幸 \\
松橋 & 信行 & 高久 & 史麿* & 海江田蒙児**
\end{tabular}

新しい廆瘍マーカーATM-1は，健常者末梢血リンパ 球より樹立されたリンホカイン活性化キラー細胞 (LAK 細胞)株5B5の認識する標的抗原であり，多くの ヒト癌細胞株に存在し，その培養上清中に放出されて いる1). ATM-1は分子量約 120 万, 70万，12万の糖蛋白 として存在するが，高分子ATM-1は分子量12万の分 子の重合体と考学られている. ATM-1に対し作製した マウスモノクローナル抗体を用いたサンドイッチエン ザイムイムノアッセイ（EIA）により，各種癌患者血清 において予備的検討を行ったところ，肝細胞癌（以下 肝癌), 乳癌, 胃癌, 肺癌患者の血清中にはATM-1の 存在が認められたが，血液悪性腫洦患者の血清中には 認められなかった。今回私達は，肝癌患者及び慢性肝 疾患患者において血清 ATM-1を測定し，ATM-1は肝

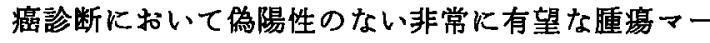
カーであるとの結果を得たので報告する.

対象及ひ方法：肝癌患者44例，慢性肝疾患患者36例 (肝硬変23例, 慢性肝炎13例), 健常者49例を対象とし た。血清 ATM-1濃度は, 先に報告した方法により EIA にて測定した1)．血清 ATM-1の測定限界は1unit $/ \mathrm{m} l$ であり, 100units $/ \mathrm{m} l$ まで良好な検量線が得られた。乳 び血清および溶血血清，それぞれ 2 検体にATM-1高 濃度血清を添加し，ATM-1の回収を見たところ，それ ぞれ93\%，103\%及び105\%，91\%であり，乳び及び溶 血の測定系への影響は認められなかった，血清 AFP は，栄研製のキットを用い，ラジオイムノフッセイに より測定した。測定限界は $5 \mathrm{ng} / \mathrm{m} l$ であり，測定限界以 下の場合は，濃度は $2.5 \mathrm{ng} / \mathrm{m} l$ とした。

結果：健常者の血清 ATM-1は全例5units $/ \mathrm{m} l$ 以下 であり，正常上限を5units $/ \mathrm{m} l$ とし，この値をこえるす のを陽性とした. 肝癌患者44例の血清 ATM-1濃度は1 unit $/ \mathrm{m} l$ か 5187 units $/ \mathrm{m} l$ にわたり，中央値は15 units/ml であった (Fig. 1). 血清 ATM-1陽性は33例

* 東京大学第 3 内科

** 旭化成医療科学研究所

〈受付日62年11月 2 日 $>$

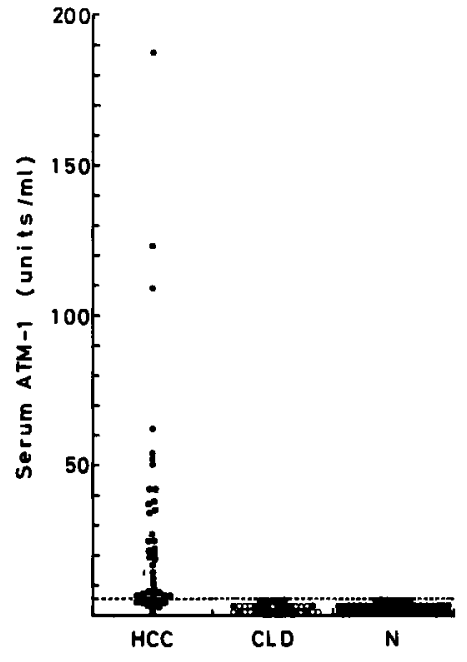

Fig. 1 Serum ATM-1 levels in patients with hepatocellular carcinoma (HCC), those with chronic liver disease (CLD) and normal controls (N). Open circles and closed circles in CLD indicate patients with chronic hepatitis and those with cirrhosis of the liver, respectively.

(75\%)に認められた。一方, 慢性肝疾患患者36例では， 血清 ATM-1濃度は全例5units $/ \mathrm{m} l$ 以下であり，陽性 例はなかった。 血清 AFP 濃度は, 肝癌患者44例中37例 (84\%) で正常上限 $(20 \mathrm{ng} / \mathrm{ml})$ をこえていたが，慢性 肝疾患患者でも36例中 8 例（22\%）で正常上限をこえ ていた．肝癌に診断的と言われる500 $\mathrm{ng} / \mathrm{m} l$ を血清 AFP 値の上限とすると, 慢性肝疾患患者の陽性者はな くなったが，肝癌の診断率は41\%に低下した，肝癌患 者において, 血清 ATM-1と血清 AFP の間には相関は 認められなかった(Fig. 2). 血清 ATM-1と血清 AFP を組み合わせた場合，両者共に陰性は 2 例 (4.5\%)の みで，両者の組合せにより診断率は向上した。腫瘍の 大きさと血清 ATM-1值の間には相関は認められな かった。 また，長径が3cm 以下の小肝癌11例中 9 例で 血清 ATM-1は陽性であり，血清 ATM-1の測定は小肝 


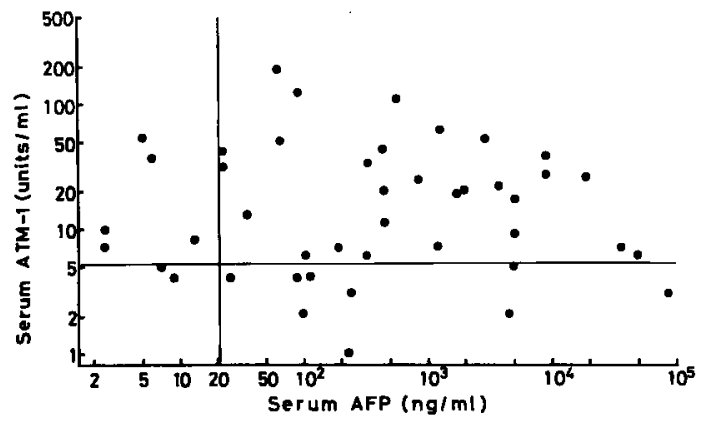

Fig. 2 Relationship between serum ATM-1 and AFP levels in patients with hepatocellular carcinoma.

癌の発見に有用と考兄られた。肝動脈塞栓術 (TAE) 前と術後 7 日目の血清が得られ，術前血清 ATM-1値 の高かった20例の検討では， 1 例を除いて全例で TAEにより平均 $50 \%$ 以上の ATM-1の低下が認めら れ，同一症例における血清 ATM-1測定は肝癌に対す る治療効果, あるいはその経過をモニターするのに有 用と考えられた。

考察：近年肝硬変患者に扎いて，肝癌合併の増加が
認められ, 肝癌の早期診断のため, 血清 AFP の湘定と 腹部超音波検查が定期的に行われている。しかしなが ら, 血清 AFP は肝癌に対し感度が高いが, 慢性肝疾患 に和いても一部上昇が認められる2)。た，腹部超音波 検查では，非常に小さいため，あるいは解剖学的位置 の関係で肝癌の発見が遅れることがある，今回報告し た LAK 細胞株の標的抗原である ATM-1は, 多くの種 類の癌で血清陽性に出ると共に，肝癌の診断において は感度が高く，偽陽性例は認めなかった，血清 ATM1值と肝癌の大ささの間には相関はなく，小肝癌に扣い ても高頻度に血清 ATM-1陽性が認められ, 血清 ATM-1の测定は慢性肝疾患のフォローアップにおい $て$, 血清 AFP の測定, 腹部超音波検査と共に有用な検 查になるるのと考えられる。ざ，血清 ATM-1の高い 症例においては, 血清 ATM-1の剆定は, 治療の効果を モニターする上で，血清 AFP の測定と同様に有用と 考えられる。

真引用語：肝細胞癌, 腫瘍マーカー, ATM-1

文 献：1) Kaieda T, Imawari M, Yamasaki Z, et al : Cancer Res(投稿中) 2) 遠藤康夫, 飯野四郎, 宮崎 純：日本臨牀 $43: 421-424,1985$

\section{Clinical significance of a new tumor-associated antigen, ATM-1 in hepatocellular carcinoma}

Michio ImaWarI, Ikuo NaKamura, Shin OHNISHI, Takashi IshIKaWA, Takashi MoRIYama, Hiroyuki ABURATaNI, Nobuyuki MatsuHashI, Fumimaro TAKAKU* and Takeji KAIEDA**

\footnotetext{
* The Third Department of Internal Medicine, University of Tokyo (Tokyo)

** Life Science Laboratories, Asahi Chemical Industry Co. LTD. (Fuji)
} 